\title{
Synthesis, Characterization and Spectrophotometric Studies of Seven Novel Antibacterial Hydrophilic Iron(II) Schiff Base Amino Acid Complexes
}

\author{
Ali M. Shaker, Lobna A. E. Nassr, Mohamed S. S. Adam, and Ibrahim M. A. Mohamed* \\ Chemistry Department, Faculty of Science, 82524, Sohag University, Sohag, Egypt. \\ ${ }^{*}$ E-mail: imaashour20080@yahoo.com
}

(Received May 7, 2013; Accepted June 11, 2013)

\begin{abstract}
A series of new Iron(II) Schiff base amino acid complexes derived from the condensation of amino acid and sodium 2-hydroxybenzaldehyde-5-sulfonate have been synthesized. The complexes were characterized by elemental, electronic, IR spectral analyses and conductance measurements. The stability and solubility of the prepared complexes were determined. Two spectral methods used to determine the stoichiometry of the prepared complexes which exhibited divalent tridentate coordination and formed chelates of octahedral structures. The antibacterial activity of the prepared complexes has been tested against Bacillus cereus, Pseudomonas aeruginosa and Micrococcus bacteria. The effect of $\mathrm{HCl}$ on investigated complexes studied spectrophotometrically.
\end{abstract}

Key words: Schiff base complex, Amino acid, Bio-inorganic chemistry, Spectrophotomtric study

\section{INTRODUCTION}

Salicylaldehyde-amino acid Schiff base complexes are used as non-enzymatic models for the metal - pyridoxal (vitamin B6) amino acid Schiff base systems which are the key intermediates in many metabolic reactions of amino acids catalyzed by enzymes which require pyridoxal as a cofactor (transamination, decarboxylation, elimination, racemization, etc.). ${ }^{1}$ Over the past few years, there have been many reports on Schiff base applications in homogeneous and heterogeneous catalysis, ${ }^{2}$ e.g., epoxidation of alkenes, ${ }^{3}$ cyclopropanation reaction, ${ }^{4}$ asymmetric hydrosilylation of ketones, ${ }^{5}$ selective oxidation of alcohols to corresponding carbonyl compounds, ${ }^{6}$ controlled ring-opening polymerization, ${ }^{7}$ hydrogenation of benzene under mild conditions, ${ }^{8}$ hydrogenation of ketones, ${ }^{9}$ Suzuki cross-coupling reaction under ambient condition ${ }^{10}$ and enantioselective oxidation of methyl aryl sulfides. ${ }^{11}$ In the area of bio-inorganic chemistry, transition metal complexes of Schiff bases have attracted a lot of interest due to their potent biological activities such as antifungal, antibacterial, anticancer and herbicidal applications. ${ }^{12-14}$ These studies have shown that complexation of metals to Schiff base ligands improves the antimicrobial and anticancer activities of the ligands. ${ }^{13}$ Some research groups found that the Schiff base metal complexes derived from salicylaldehyde can specially cleave the DNA. ${ }^{15-17}$ Water soluble complexes of sulphonato - substituted Schiff base ligands used as catalytic antioxidants..$^{18}$ Comparatively very little effort has been expended to prepare Iron(II) Schiff base amino acid complexes ${ }^{19-21}$ despite their importance as complexes containing a metal in unstable, low oxidation state, as well as involving unstable ligands, the Schiff base amino acid, that forms through coordination to $\mathrm{Fe}(\mathrm{II})$ metal ion. Therefore, in this work we prepared seven novel Fe(II) Schiff base amino acid complexes and characterized their structures by various possible physical methods to obtain more information about their structures.

\section{EXPERIMENTAL}

\section{Reagents and Instrumentation}

All the used amino acids and $\left(\mathrm{NH}_{4}\right)_{2} \mathrm{Fe}\left(\mathrm{SO}_{4}\right)_{2} \cdot 6 \mathrm{H}_{2} \mathrm{O}$ in the present study are of analytical grade purchased from Sigma Aldrich, sodium 2-hydroxybenzaldehyde-5-sulfonate was prepared according to literature. ${ }^{22}$ Conductivity measurements were made at $25^{\circ} \mathrm{C}$ on Jenway Conductivity meter 4320 using bidistilled water as solvent. The electronic spectra of the complexes were monitored using matched $1 \mathrm{~cm}$ silica cells on Perkin Elmer Lambda 35 spectrophotometer and IR spectra of the metal chelates recorded over the $400-4000 \mathrm{~cm}^{-1}$ range on a Shimadzu FTIR-8101 Fourier transform infrared spectrophotometer using $\mathrm{KBr}$ discs. Elemental analyses were carried out at the Micro analytical Center, Assiut University, Egypt.

\section{Synthesis of Schiff Base Metal Complexes}

$2 \mathrm{mmol}(0.448 \mathrm{~g})$ of sodium 2-hydroxybenzaldehyde-5sulfonate in de-ionized water $(20 \mathrm{ml})$ was added dropwise 
to an equimolar aqueous solution of amino acid; $1,0.15 \mathrm{~g}$ Glycine in de-ionized water $(10 \mathrm{ml}) ; 2,0.178 \mathrm{~g} \mathrm{~L}$-alanine in de-ionized water $(10 \mathrm{ml}) ; 3,0.262 \mathrm{~g}$ L-leucine in deionized water $(15 \mathrm{ml}) ; 4,0.262 \mathrm{~g}$ L-Isoleucine in de-ionized water $(15 \mathrm{ml}) ; \mathbf{5}, 0.298 \mathrm{~g}$ DL-methionine in de-ionized water $(15 \mathrm{ml}) ; 6$, $0.21 \mathrm{~g}$ DL-serine in de-ionized water $(10 \mathrm{ml})$; 7, $0.33 \mathrm{~g}$ L-phenylalanine in de-ionized water $(10 \mathrm{ml})$ then the mixture was stirred at $100{ }^{\circ} \mathrm{C}$ for $3 \mathrm{~h}$ to give yellow color. Then the obtained ligand solution was mixed with an equimolar aqueous solution of ferrous ammonium sulphate. In order to avoid the oxidation of ferrous to ferric, a few drops of Glacial acetic acid were added. ${ }^{19-21}$ The resulting solution was stirred at $40{ }^{\circ} \mathrm{C}$ for $10 \mathrm{~h}$ (Its color becomes deep violet), then the obtained solution was evaporated under room temperature. The solid obtained was filtered-off, washed several times with ether, and then recrystallized from ethanol - water mixture (2:1). All the complexes were prepared by similar procedure.

\section{Antibacterial Activity}

The Inhibitory effect of the prepared Schiff base complexes on the in vitro growth of bacteria representing one gram negative bacterium, Pseudomonus aeruginosa and two gram positive bacteria, Bacillus Cereus and Micrococcus was evaluated using agar diffusion method ${ }^{23,24}$ by measuring the zone of inhibition on agar plates at two different concentrations $3 \mathrm{mg} / \mathrm{ml}$ and $6 \mathrm{mg} / \mathrm{ml}$. De-ionized water was used as solvent control. All plates were incubated at $37 \pm 0.5^{\circ} \mathrm{C}$ for $24 \mathrm{~h}$.

\section{RESULTS AND DISCUSSION}

All the complexes are soluble in bidistilled water and in

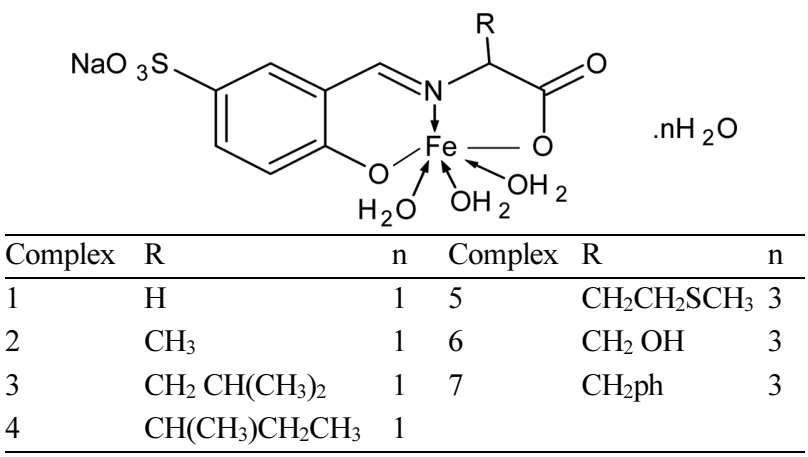

Scheme 1.

two organic solvents (ethanol and methanol), but partially soluble in acetone. The suggested structures of the prepared complexes are listed in Scheme 1 and general properties listed in Table 1.

\section{Infrared Spectra}

The IR spectral data containing the relevant vibrational bands of Fe(II) complexes are listed in Table 2. The absorption bands around $1625 \mathrm{~cm}^{-1}$ is corresponding to azomethine group $(\mathrm{N}=\mathrm{C})^{25,26}$ and around $1100 \mathrm{~cm}^{-1}$ is related to $\mathrm{S}=\mathrm{O}$ bond, ${ }^{27}$ the disappearance of the peak around $1650 \mathrm{~cm}^{-1}$ shows that the product does not contain 5-sulfosalicylaldehyde. ${ }^{28}$ The IR results showed that the metal coordinated to nitrogen (azomethine) and oxygen (carboxylato) atoms of the amino acid groups besides water molecules.

\section{Electronic Spectra}

The electronic spectra of the aqueous solutions of the prepared $\mathrm{Fe}(\mathrm{II})$ complexes display maximum absorption bands around $325 \mathrm{~nm}\left(\epsilon=3596-4685 \mathrm{dm}^{3} \mathrm{~mol}^{-1} \mathrm{~cm}^{-1}\right)$.

Table 1. General properties of the prepared complexes

\begin{tabular}{|c|c|c|c|c|c|}
\hline \multirow{2}{*}{ No. } & \multirow{2}{*}{ Empirical formula } & \multirow{2}{*}{$\begin{array}{l}\text { Molar conductance } \\
\left(\mathrm{ohm}^{-1} \mathrm{~cm}^{2} \mathrm{~mol}^{-1}\right)\end{array}$} & \multirow{2}{*}{ M.P. $\left({ }^{\circ} \mathrm{C}\right)$} & \multicolumn{2}{|c|}{ Electronic spectra } \\
\hline & & & & $\lambda_{\max }, \mathrm{nm}$ & $\epsilon_{\max }, \mathrm{M}^{-1} \mathrm{~cm}^{-1}$ \\
\hline \multirow{2}{*}{1} & \multirow{2}{*}{$\mathrm{FeC}_{9} \mathrm{H}_{14} \mathrm{NO}_{10} \mathrm{SNa}$} & \multirow{2}{*}{106} & \multirow{2}{*}{$>350{ }^{\circ} \mathrm{C}$} & 505 & 644.71 \\
\hline & & & & 320 & 3596.34 \\
\hline \multirow{2}{*}{2} & \multirow{2}{*}{$\mathrm{FeC}_{10} \mathrm{H}_{16} \mathrm{NO}_{10} \mathrm{SNa}$} & \multirow{2}{*}{108} & \multirow{2}{*}{$>350{ }^{\circ} \mathrm{C}$} & 504 & 668.73 \\
\hline & & & & 321 & 3809.51 \\
\hline \multirow{2}{*}{3} & \multirow{2}{*}{$\mathrm{FeC}_{13} \mathrm{H}_{22} \mathrm{NO}_{10} \mathrm{SNa}$} & \multirow{2}{*}{112} & \multirow{2}{*}{$>350^{\circ} \mathrm{C}$} & 502 & 694.46 \\
\hline & & & & 324 & 3969.14 \\
\hline \multirow{2}{*}{4} & \multirow{2}{*}{$\mathrm{FeC}_{13} \mathrm{H}_{22} \mathrm{NO}_{10} \mathrm{SNa}$} & \multirow{2}{*}{114} & \multirow{2}{*}{$>350^{\circ} \mathrm{C}$} & 500 & 711.57 \\
\hline & & & & 321 & 4010.23 \\
\hline \multirow{2}{*}{5} & \multirow{2}{*}{$\mathrm{FeC}_{12} \mathrm{H}_{24} \mathrm{~N} \mathrm{O}_{12} \mathrm{~S}_{2} \mathrm{Na}$} & \multirow{2}{*}{120} & \multirow{2}{*}{$>350{ }^{\circ} \mathrm{C}$} & 499 & 727.03 \\
\hline & & & & 320 & 4286.97 \\
\hline \multirow{2}{*}{6} & \multirow{2}{*}{$\mathrm{FeC}_{10} \mathrm{H}_{20} \mathrm{NO}_{13} \mathrm{SNa}$} & \multirow{2}{*}{125} & \multirow{2}{*}{$>350{ }^{\circ} \mathrm{C}$} & 508 & 637.87 \\
\hline & & & & 322 & 3709.21 \\
\hline \multirow{2}{*}{7} & \multirow{2}{*}{$\mathrm{FeC}_{16} \mathrm{H}_{24} \mathrm{NO}_{12} \mathrm{SNa}$} & \multirow{2}{*}{98} & \multirow{2}{*}{$>350{ }^{\circ} \mathrm{C}$} & 509 & 768.19 \\
\hline & & & & 322 & 4685 \\
\hline
\end{tabular}


Table 2. The infrared absorption frequencies $\left(\mathrm{cm}^{-1}\right)$ of the investigated Fe (II) Schiff base amino acid complexes

\begin{tabular}{ccccccc}
\hline Complex & $\mathrm{H}_{2} \mathrm{O}$ & $\mathrm{C}=\mathrm{N}$ & $\mathrm{C}=\mathrm{C}$ & $\mathrm{S}=\mathrm{O}$ & $\mathrm{M}-\mathrm{O}$ & $\mathrm{M}-\mathrm{N}$ \\
\hline 1 & 3114.5 & 1625.2 & 1435.2 & 1135.2 & 741.7 & 620.2 \\
2 & 3205.1 & 1626.2 & 1416.9 & 1118.8 & 819.8 & 614.4 \\
3 & 3217.7 & 1635.8 & 1409.2 & 1112.1 & 731.1 & 612.5 \\
4 & 3209.9 & 1636.8 & 1439.1 & 1097.6 & 817.9 & 616.3 \\
5 & 3192.6 & 1632.0 & 1413.0 & 1116.0 & 823.7 & 615.4 \\
6 & 3442.4 & 1637.8 & 1399.5 & 1128.5 & 815.4 & 687.7 \\
7 & 3199.3 & 1616.5 & 1437.1 & 1138.1 & 746.5 & 612.5 \\
\hline
\end{tabular}

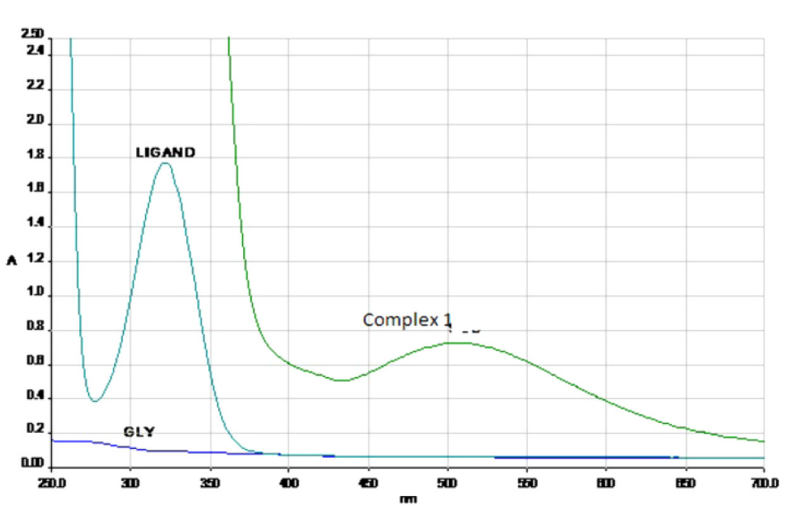

Figure 1. The electronic spectra of complex 1 and its components.

This band can be ascribed to an intramolecular charge transfer transition taking place in the complexed ligand. In addition, a band shown around $500 \mathrm{~nm}\left(€=637-769 \mathrm{M}^{-1} \mathrm{~cm}^{-1}\right)$ may be attributable to a d-d transition in an octahedral structure for such complexes. Fig. 1 shows the comparison between complex 1, its ligand and the corresponding amino acid (Glycine).

\section{Elemental Analysis and Electrical Conductivity}

The obtained elemental analyses of the metal complexes are listed in Table 3. The obtained data are in agreement with the calculated values showing that the complexes have (1:1) metal/ligand ratio as in Scheme 1.

The observed molar conductance values of the 1:1 complexes of $1 \times 10^{-3} \mathrm{M}$ aqueous solutions of the prepared complexes at $25^{\circ} \mathrm{C}$ are consistent with the electrolytic nature of the (1:1) complexes due to the presence of $-\mathrm{SO}_{3} \mathrm{Na}$ group in the proposed structures of the Schiff base metal complexes.

The electrical conductivity of the prepared complexes is determined at different temperatures (Table 4), the acti-

Table 3. The elemental analyses and magnetic moment of the investigated complexes

\begin{tabular}{|c|c|c|c|c|c|}
\hline \multirow{2}{*}{ Complex } & \multicolumn{4}{|c|}{ Found (calculated) (\%) } & \multirow{2}{*}{$\mu_{\mathrm{eff}}(\mathrm{BM})$} \\
\hline & $\mathrm{C}$ & $\mathrm{H}$ & $\mathrm{N}$ & $\mathrm{S}$ & \\
\hline 1 & $27.11(26.55)$ & $2.97(3.47)$ & $3.39(3.44)$ & $7.16(7.88)$ & 3.96 \\
\hline 2 & $27.91(28.52)$ & $3.23(3.83)$ & $2.97(3.33)$ & $7.11(7.61)$ & 3.99 \\
\hline 3 & $33.98(33.71)$ & $4.32(4.79)$ & $2.59(3.02)$ & $6.40(6.92)$ & 4.01 \\
\hline 4 & $33.91(33.71)$ & $4.42(4.79)$ & $2.64(3.02)$ & $6.39(6.92)$ & 4.03 \\
\hline 5 & $27.37(27.86)$ & $4.38(4.68)$ & $2.51(2.71)$ & $11.95(12.40)$ & 4.06 \\
\hline 6 & $24.91(25.38)$ & $3.91(4.26)$ & $2.99(2.96)$ & $6.38(6.78)$ & 4.1 \\
\hline 7 & $35.54(36.04)$ & $4.94(4.54)$ & $2.34(2.63)$ & $5.95(6.01)$ & 4.18 \\
\hline
\end{tabular}

Table 4. The observed conductivity $(\sigma, \mu \mathrm{S})$ and activation energy of the prepared complexes

\begin{tabular}{|c|c|c|c|c|c|c|c|}
\hline \multirow{2}{*}{ Complex T, K } & \multicolumn{7}{|c|}{$\sigma, \mu \mathrm{S}$} \\
\hline & 1 & 2 & 3 & 4 & 5 & 6 & 7 \\
\hline 283 & 99 & 100 & 101 & 102 & 103 & 104 & 91 \\
\hline 288 & 102 & 102 & 104 & 106 & 108 & 110 & 93 \\
\hline 293 & 104 & 106 & 107 & 110 & 114 & 117 & 95 \\
\hline 298 & 106 & 109 & 113 & 114 & 120 & 124 & 98 \\
\hline 303 & 109 & 112 & 116 & 118 & 126 & 130 & 101 \\
\hline 308 & 112 & 114 & 119 & 123 & 131 & 134 & 103 \\
\hline 313 & 116 & 117 & 121 & 127 & 135 & 138 & 106 \\
\hline $\mathrm{E}, \mathrm{kJ} / \mathrm{mol}$ & 7.45 & 7.88 & 9.40 & 10.78 & 13.68 & 14.24 & 7.60 \\
\hline
\end{tabular}




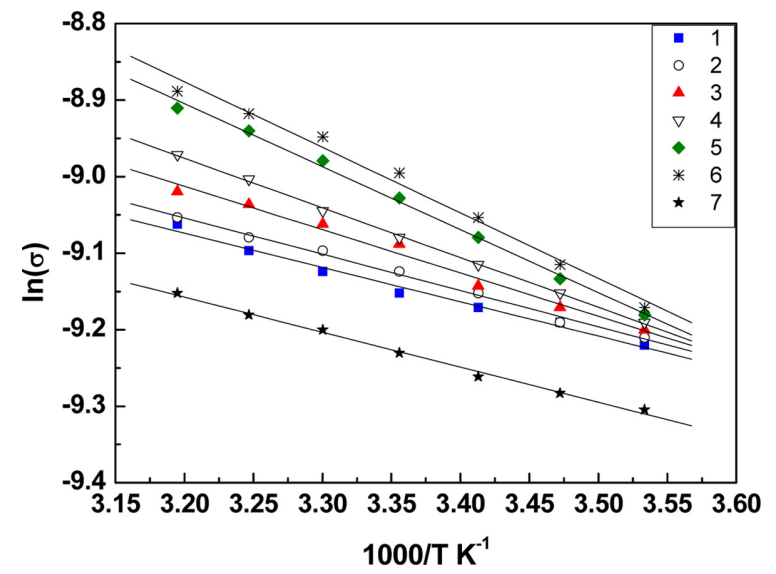

Figure 2. The relation between $\ln \sigma$ against $1 / \mathrm{T}$ for all the investigated complexes.

vation energies of charged ions in the complexes solutions were calculated from the following equation:

$$
\sigma=\sigma_{0} \mathrm{e}^{(-\mathrm{E} / 2 \mathrm{KT})}
$$

where $\sigma, \sigma_{0}, \mathrm{E}$, and $\mathrm{k}$ are the observed conductance, conductivity constant, activation energy, and Boltzman constant, respectively ${ }^{29,30}$ Fig. 2 shows the relation between $\ln \sigma$ against $1 / T$ for all the investigated complexes, From the slopes of the linear plots, the values of $\mathrm{E}$ were calculated. The conductivity of the investigated complexes increases with increasing temperature, hence all complexes exhibit semiconducting properties.

\section{Determination of the Stoichiometry of the Complexes}

The stoichiometry of the tested complexes were determined by applying the spectrophotometric molar ratio ${ }^{19,21}$

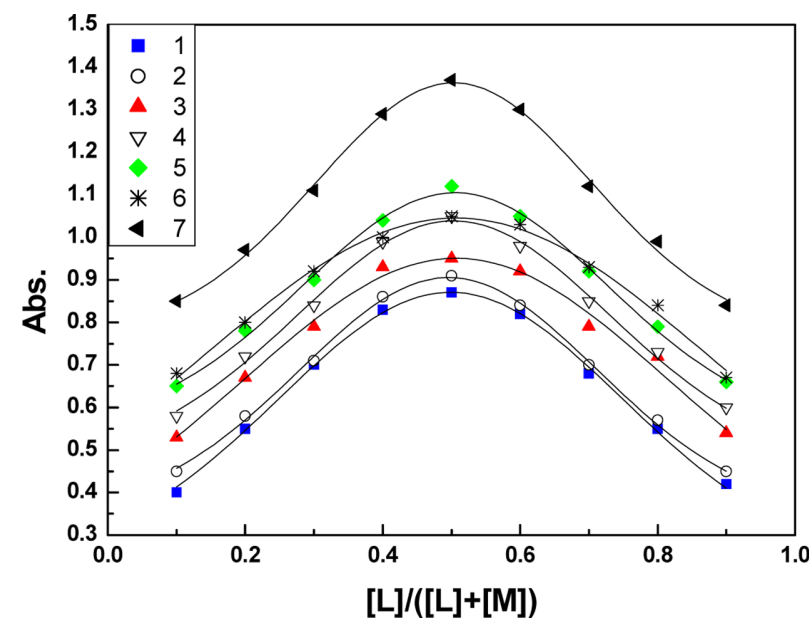

Figure 3. Continuous variation plot of Fe(II) Schiff base amino acid complexes in aqueous medium at $\left[\mathrm{Fe}^{2+}\right]+[\mathrm{L}]=5 \times 10^{-3} \mathrm{~mol} \mathrm{dm}^{-3}$ and $298 \mathrm{~K}$ against $\left[\mathrm{Fe}^{2+}\right.$-ald.], as a blank, with the same concentration as in the test solution.

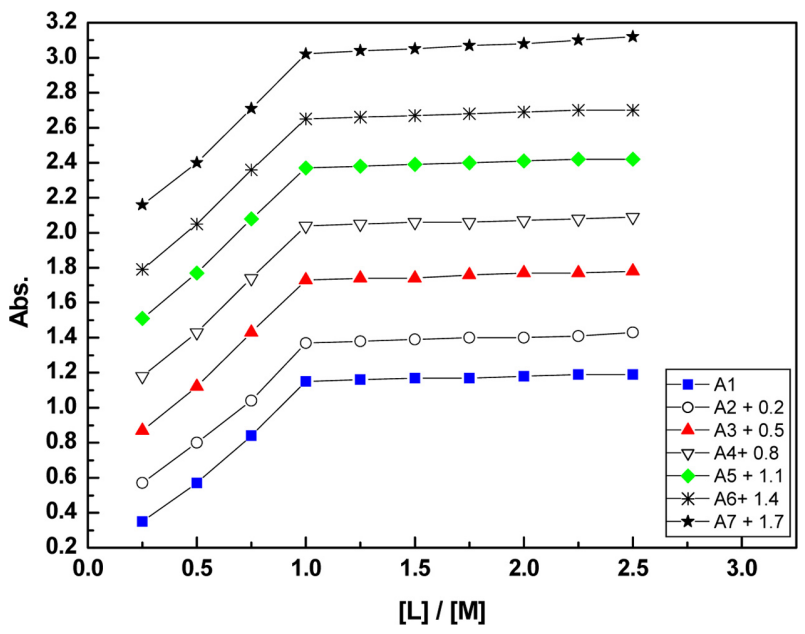

Figure 4. Molar ratio plots of Fe(II) Schiff base amino acid complexes in aqueous medium at $\left[\mathrm{Fe}^{2+}\right]=7.5 \times 10^{-3} \mathrm{~mol} \mathrm{dm} \mathrm{dm}^{-3}$ and $298 \mathrm{~K}$ against $\left[\mathrm{Fe}^{2+}\right.$-ald.], as a blank, of the same concentration as in the test solution.

and continuous variation methods ${ }^{19,21}$ (cf. Figs. 3 and 4). The results suggested the possible formation of 1:1 complexes (Iron(II): Schiff base amino acid ligand).

\section{Magnetic Moment Measurements}

Magnetic susceptibility measurements showed that the prepared complexes have paramagnetic character and suggested high spin values i.e., the studied Schiff base amino acid ligands are so weak that they exhibited low $\mathrm{t}_{2 \mathrm{~g}}$ and $\mathrm{e}_{\mathrm{g}}$ d-splitting of the octahedral structures of the complexes. ${ }^{31,32}$

\section{Apparent Formation Constant}

The apparent formation constants $\left(\mathrm{K}_{\mathrm{f}}\right)$ of the synthesized complexes formed in solution were determined from spectrophotometric measurements using the continuous variation method ${ }^{21}$ (cf. Table 5). The obtained $\mathrm{K}_{\mathrm{f}}$ values indicate the stability of these complexes.

\section{Stability pH Range of the Investigated Complexes}

The stability range of the studied complexes was found

Table 5. The formation constants $\left(\mathrm{K}_{\mathrm{f}}\right)$, stability constants $(\mathrm{pK})$ and Gibbs free energy $(\Delta \mathrm{G})$ values of the prepared complexes in aqueous medium at $298 \mathrm{~K}$

\begin{tabular}{cccc}
\hline Complex & $10^{-5} \mathrm{~K}_{\mathrm{f}}$ & $\mathrm{pK}$ & $\Delta \mathrm{G}, \mathrm{kJ} / \mathrm{mol}$ \\
\hline 1 & 1.01 & 5.01 & -28.55 \\
2 & 1.86 & 5.27 & -30.06 \\
3 & 2.07 & 5.32 & -30.33 \\
4 & 1.43 & 5.16 & -29.41 \\
5 & 2.86 & 5.46 & -31.13 \\
6 & 5.51 & 5.74 & -32.75 \\
7 & 1.58 & 5.20 & -29.66 \\
\hline
\end{tabular}




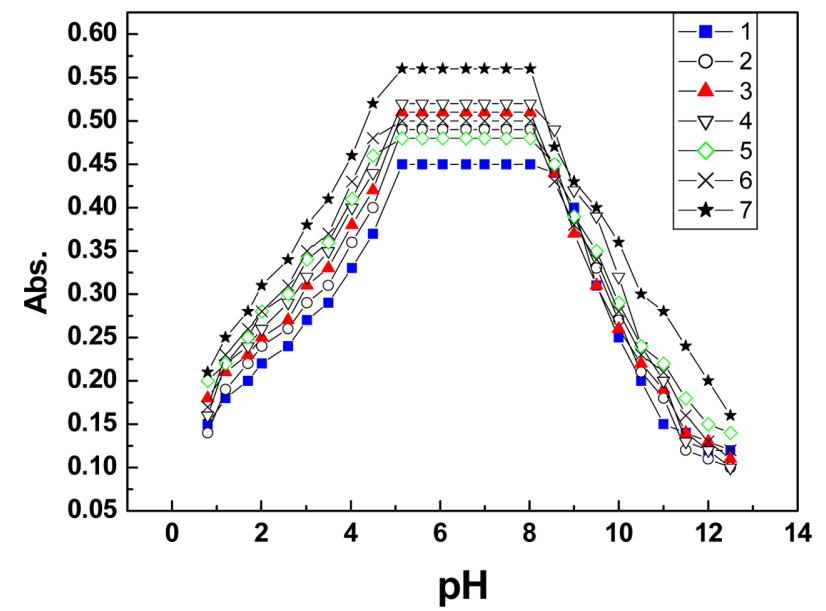

Figure 5. pH-absorbance plots of Fe (II) Schiff base amino acid complexes at $1 \times 10^{-3} \mathrm{M}$ in aqueous medium at $298 \mathrm{~K}$.

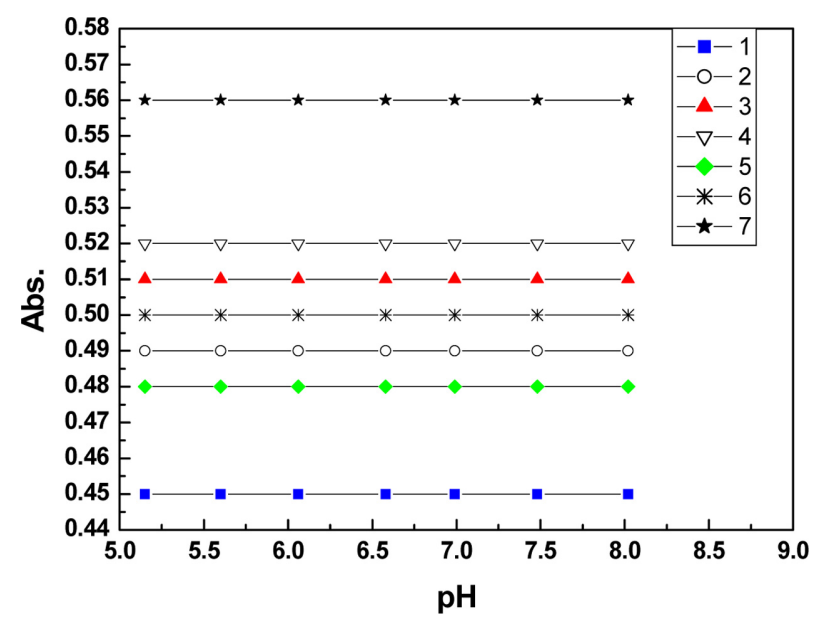

Figure 6. pH-absorbance plots of $\mathrm{Fe}$ (II) complexes in aqueous medium at $298 \mathrm{~K}$ in stability range $(\mathrm{pH}=5-8)$.

to be from $\mathrm{pH}=5$ to $\mathrm{pH}=8$ according to the obtained $\mathrm{pH}$ absorbance curves (cf. Figs. 5 and 6). This means that Fe(II) ion greatly stabilizes the tested Schiff base amino acid ligands in this range. Accordingly, these ligands can be used as masking reagents of $\mathrm{Fe}^{2+}$ ions in that range of $\mathrm{pH}$.

\section{Determination of the Solubility of the Investigated Complexes}

The solubility of the prepared complexes was measured in aqueous solution, $10 \%, 30 \%$ and $50 \%$ aqueous methanol as a solvent. A saturated solution of the solid was agitated with the appropriate solvent at $298 \mathrm{~K}$. The mixture was centrifuged then an aliquot of the saturated solution removed. The obtained complexes solutions were diluted and their absorbance values measured at $\lambda_{\max }$ for each one. ${ }^{19,33}$ The solubility values and transfer chemical potentials are cited in Table 6, on the assumption that the ratio of mean activity co-efficients in the aqueous and aqueous methanol mixtures are in all cases unity. The values of the transfer chemical potentials $\delta_{\mathrm{m}} \mu^{\varphi}$, of the investigated complexes from water to water-methanol binary mixtures, were estimated by applying the following equation: $\delta_{\mathrm{m}} \mu^{\varphi}=-\mathrm{RT}$ $\ln \left(\mathrm{S}_{\mathrm{s}} / \mathrm{S}_{\mathrm{w}}\right)$ where $\mathrm{S}_{\mathrm{s}}$ is the solubility in $10 \%, 30 \%$ and $50 \%$ aqueous-methanol binary mixtures and $S_{\mathrm{w}}$ the solubility in the aqueous medium. According to the solubility data, Table 3, the following ascending order of the hydrophobicity of the examined complexes was deduced: $\mathbf{1}<\mathbf{2}<\mathbf{6}$ $<\mathbf{3}<\mathbf{4}<\mathbf{5}<\mathbf{7}$.

\section{Antibacterial Activity}

The results of antibacterial activity are shown in Table 7. Investigated Schiff base complexes exhibited good activity against three types of bacteria: Bacillus cereus, Pseudomonus aeruginosa, Micrococcus (cf. Figs. 7-9). Complex derived from methionine showed the highest inhibitory effect against examined bacteria. In general the inhibition zones of the complexes were increased with increasing their concentrations. The highest inhibition zone was obtained by complex 7 against $P$ seudomonus aeruginosa where the minimum inhibition zone obtained by complex 7 against Bacillus cereus. Figs. 9-11 show the inhibition zone of complex $\mathbf{1}$ against the tested bacteria.

Table 6. Solubility $\left(\mathrm{mol} \mathrm{dm}^{-3}\right)$ and transfer chemical potential $\left(\delta_{\mathrm{m}} \mu^{\varphi}\right)$ values of the prepared complexes in water, $10 \%, 30 \%$ and $50 \%$ aqueous-methanol mixtures at $25^{\circ} \mathrm{C}$

\begin{tabular}{cccccccc}
\hline \multirow{2}{*}{ Complex } & \multicolumn{9}{c}{$\mathrm{MeOH}, \%$} & \multicolumn{3}{c}{$\delta_{\mathrm{m}} \mu^{\varphi}, \mathrm{kJ} / \mathrm{mol}$} \\
\cline { 2 - 8 } & 0 & 10 & 30 & 50 & 10 & 30 & 50 \\
\hline 1 & 0.52 & 0.44 & 0.37 & 0.30 & 0.38 & 0.83 & 1.39 \\
2 & 0.48 & 0.41 & 0.34 & 0.26 & 0.39 & 0.83 & 1.52 \\
3 & 0.35 & 0.29 & 0.21 & 0.17 & 0.45 & 0.61 & 1.82 \\
4 & 0.39 & 0.33 & 0.27 & 0.20 & 0.41 & 0.92 & 1.61 \\
5 & 0.33 & 0.28 & 0.24 & 0.22 & 0.41 & 0.76 & 1.05 \\
6 & 0.40 & 0.34 & 0.31 & 0.20 & 0.43 & 0.65 & 1.77 \\
7 & 0.28 & 0.23 & 0.18 & 0.14 & 0.48 & 1.04 & 1.67 \\
\hline
\end{tabular}


Table 7. Results of anti-bacterial evaluation of Schiff base amino acid complexes. Inhibition zone diameter in $\mathrm{cm}$

\begin{tabular}{ccccccc}
\hline Bacteria & \multicolumn{2}{c}{ Bacillus cereus } & \multicolumn{2}{c}{ Pseudomonas aeruginosa } & \multicolumn{2}{c}{ Micrococcus } \\
\hline [complex] $^{\mathrm{a}}$ & 3 & 6 & 3 & 6 & 3 & 6 \\
\hline 1 & 1.9 & 2.3 & 1.5 & 2.8 & 2 & 2.7 \\
2 & 2.5 & 2.5 & 2.7 & 3.1 & 3.2 & 3.2 \\
3 & 2.8 & 2.8 & 3.1 & 3.1 & 3.2 & 3.2 \\
4 & 2.2 & 2.2 & 3.3 & 3.3 & 2.8 & 3.2 \\
5 & 2.9 & 2.9 & 3 & 3.5 & 3.7 & 4 \\
6 & 2 & 2.4 & 1.4 & 1.8 & 2.9 & 3.6 \\
7 & 1.4 & 2.6 & 3.3 & 4.3 & 2.9 & 3.3 \\
\hline
\end{tabular}

${ }^{\mathrm{a}}[$ complex] in $\mathrm{mg} / \mathrm{ml}$.

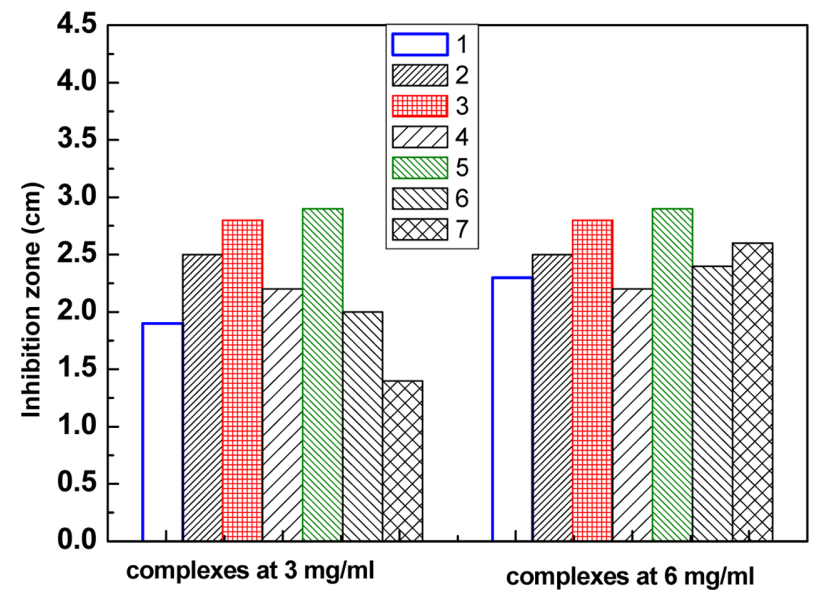

Figure 7. Plots of Inhibition zones of prepared complexes in the presence of Bacillus cereus bacteria.

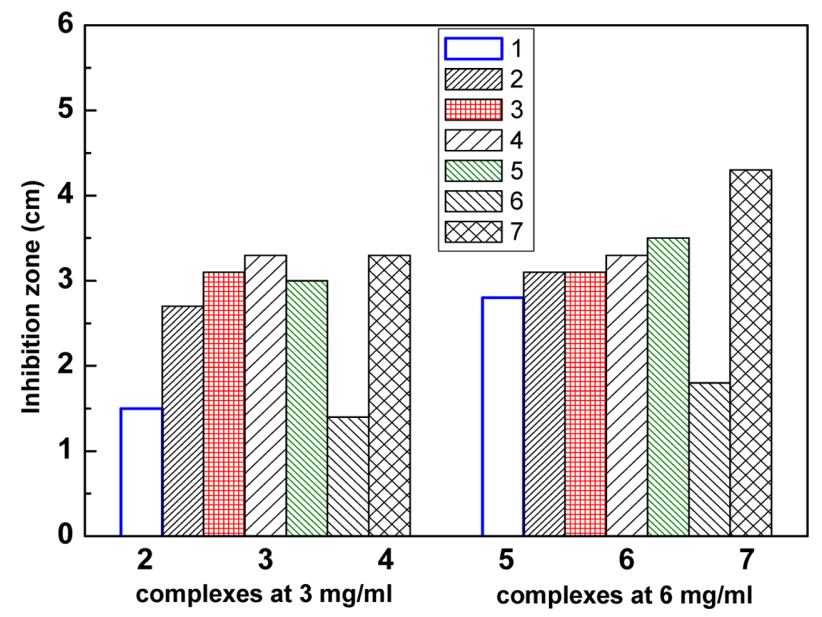

Figure 8. Plots of Inhibition zones of prepared complexes in the presence of Pseudomonus aeruginosa bacteria.

\section{Effect of HCl on Investigated Complexes Spectro- photometric Study}

Completed repeated spectral scans of prepared complexes at $[$ complex $]=1.67 \times 10^{-3} \mathrm{~mol} \mathrm{dm}^{-3}$ were carried

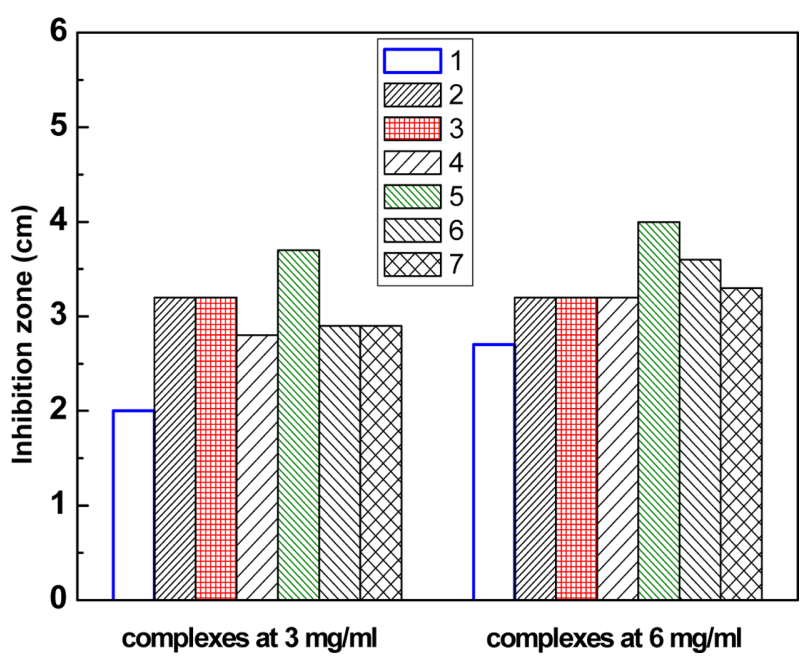

Figure 9. Plots of Inhibition zones of prepared complexes in the presence of Micrococcus bacteria.

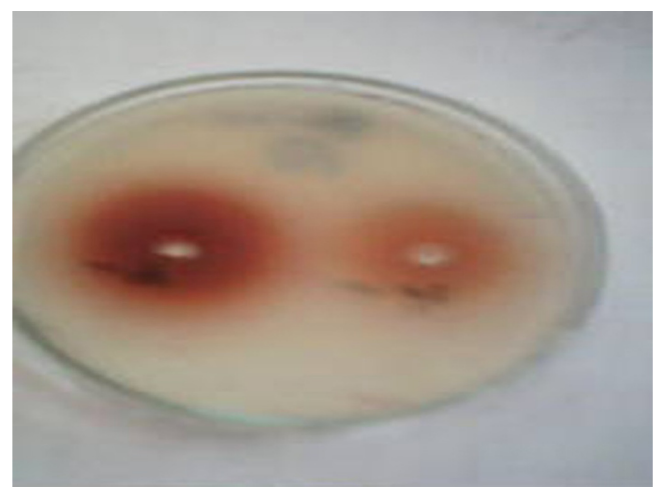

Figure 10. The inhibition zone of complex 1 against Bacillus cereus.

out before and just after addition of hydrochloric acid $(0.1 \mathrm{M})$ for a period of time with time interval $1 \mathrm{~min}$ at $298 \mathrm{~K}$, cf. Figs. 13 and 14. These results were supported by the naked eye observation that the color of the complex rapidly changed from violet to pink then decayed slowly until the solution turned colorless and optically clear at the end of 


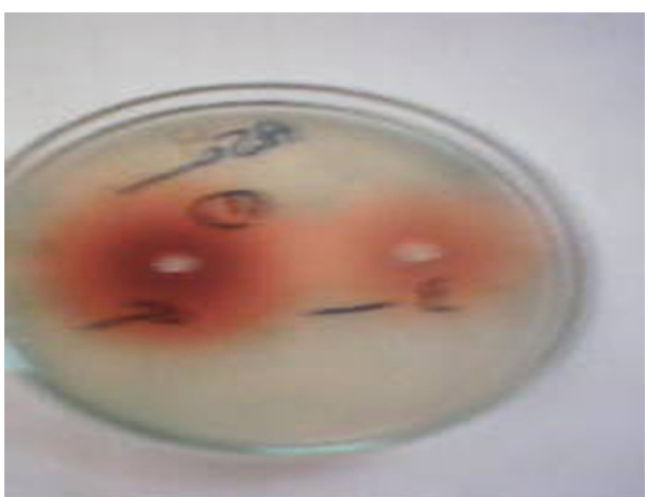

Figure 11. The inhibition zone of complex 1 against Pseudomonus aeruginosa.

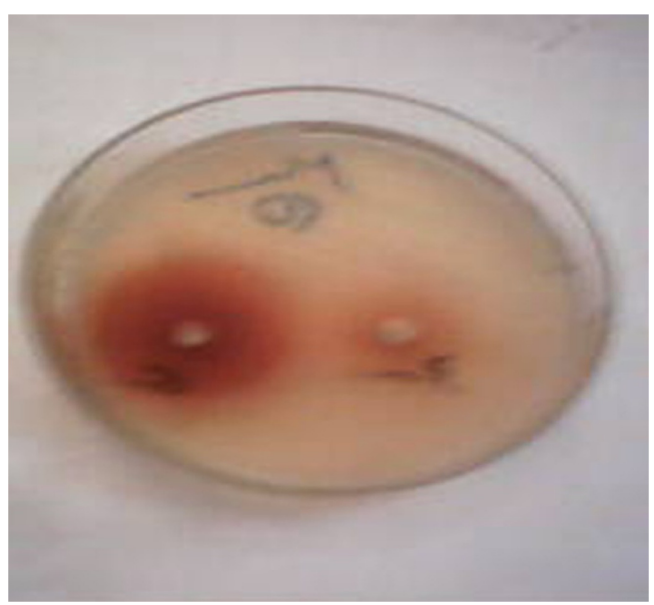

Figure 12. The inhibition zone of complex 1 against Micrococcus.

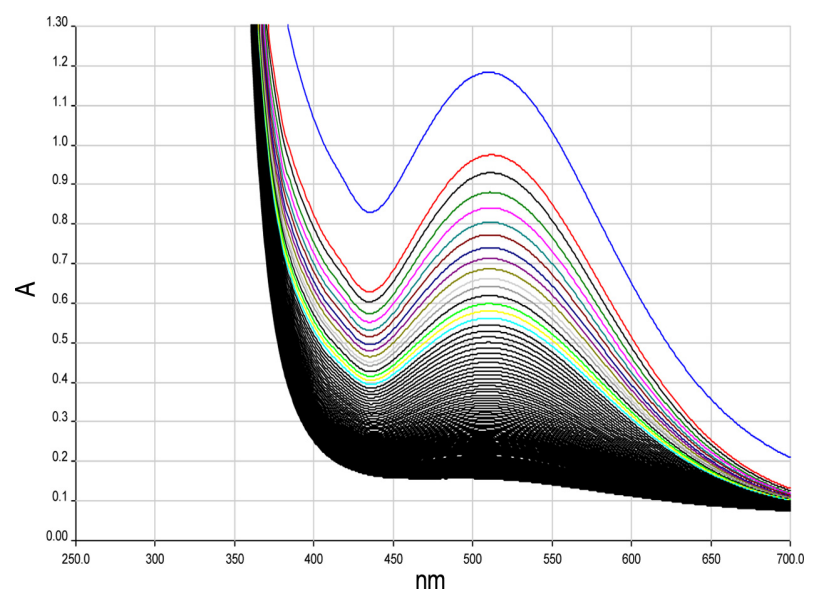

Figure 13. Repeated spectral scans of complex 4 before and after addition of $\mathrm{HCl}$ in aqueous media at $\left[\right.$ complex] $=1.67 \times 10^{-3}$ $\mathrm{mol} \mathrm{dm}{ }^{-3},[\mathrm{HCl}]=0.1 \mathrm{~mol} \mathrm{dm}^{-3}, \mathrm{I}=0.5 \mathrm{~mol} \mathrm{dm}^{-3}, \mathrm{~T}=298 \mathrm{~K}$ and interval time $1 \mathrm{~min}$.

each run. The rst-order rate constants $\left(\mathrm{k}_{\mathrm{obs}}\right)$ obtained by a least-squares procedure from the spectral scans, as shown

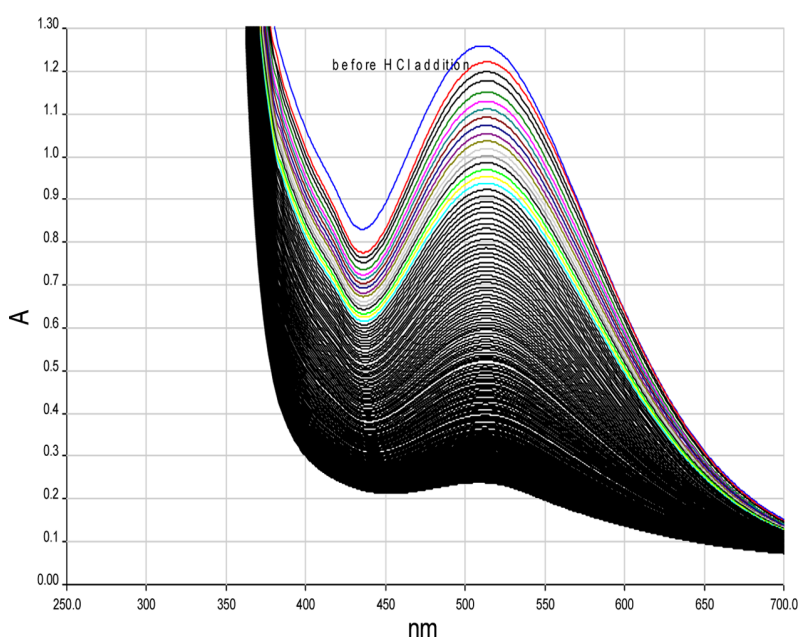

Figure 14. Repeated spectral scans of complex 7 before and after addition of $\mathrm{HCl}$ in aqueous media at [complex] $=1.67 \times 10^{-3}$ $\mathrm{mol} \mathrm{dm}{ }^{-3},[\mathrm{HCl}]=0.1 \mathrm{~mol} \mathrm{dm}^{-3}, \mathrm{I}=0.5 \mathrm{~mol} \mathrm{dm}^{-3}, \mathrm{~T}=298 \mathrm{~K}$ and interval time $1 \mathrm{~min}$.

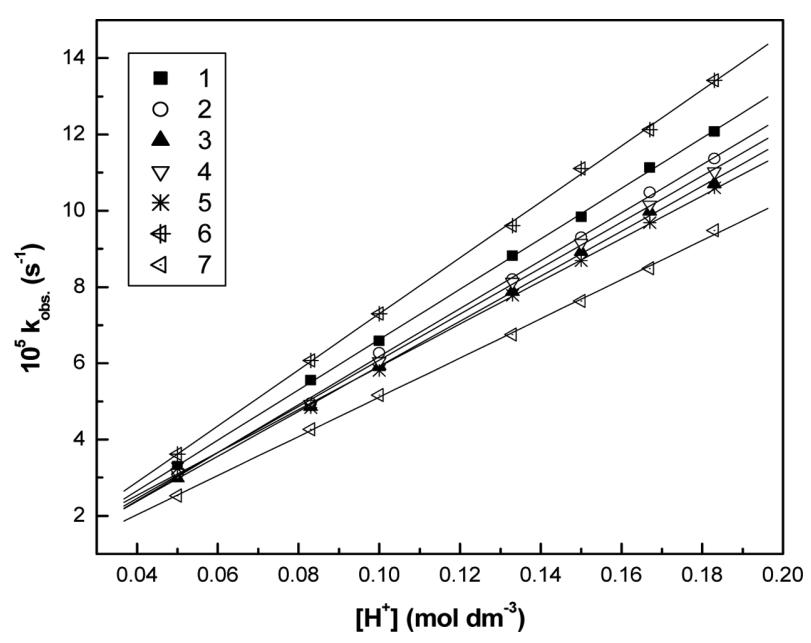

Figure 15. The relationship between $\left[\mathrm{H}^{+}\right]$and $10^{5} \mathrm{k}_{\mathrm{obs}}$. Values for hydrolysis of investigated complexes in aqueous medium with [complex] $=1.67 \times 10^{-3} \mathrm{~mol} \mathrm{dm}^{-3}, \mathrm{I}=0.5 \mathrm{~mol} \mathrm{dm}^{-3}$ and $298 \mathrm{~K}$.

in Figs. 13 and 14. Linear plots of $\mathrm{k}_{\mathrm{obs}} \mathrm{vs}\left[\mathrm{H}^{+}\right]$displayed (cf. Fig. 15) are in a good correlation with the following equation: Rate $=\mathrm{k}_{\mathrm{obs}}$ [complex]: $\mathrm{k}_{\mathrm{obs}}=k_{1}+k_{2}\left[\mathrm{H}^{+}\right]$.

\section{CONCLUSION}

Novel hydrophilic ferrous Schiff base amino acid complexes were prepared and characterized by elemental, electronic, IR spectral analyses and conductance measurements. The stability $\mathrm{pH}$ range of complexes was found to be from $\mathrm{pH}=5$ to $\mathrm{pH}=8$. The solubility and transfer chemical potentials of the complexes were determined to show 
the hydrophilicity of these complexes. The complexes showed good antibacterial activity against Bacillus cereus, Pseudomonas aeruginosa and Micrococcus bacteria. The complexes studied spectrophotometrically in the presence of $\mathrm{HCl}$.

Acknowledgments. The authors are grateful to Mr. Bahgat Ramadan Mahmoud and Ms. Dalia Ahmed Abd ElRaheem for their help in antibacterial activity test. And the publication cost of this paper was supported by the Korean Chemical Society.

\section{REFERENCES}

1. Casella, L.; M. Gullotti Inorg. Chem. 1986, 25, 1293.

2. Gupta, K. C.; Sutar, A. K. Coord. Chem. Rev. 2008, 252, 1420.

3. Grivani, G.; Khalaji, A. D.; Tahmasebi, V.; Gotoh, K.; Ishida, H. Polyhedron 2012, 31, 265.

4. Youssef, N. S.; El-Zahany, E.; El-Seidy, A. M. A.; Caselli, A.; Fantauzzi, S.; Cenini, S. Inorg. Chim. Acta 2009, 362, 2006.

5. Liu, S.; Peng, J.; Yang, H.; Bai, Y.; Li, J.; Lai, G. Tetrahedron 2012, 68, 1371.

6. Rong, M.; Wang, J.; Shen, Y.; Han, J. Catal. Commun. 2012, 20, 51.

7. Xufeng, N.; Weiwei, Z.; Zhiquan, S. Chin. J. Catal. 2010, 31, 965.

8. Chen, P.; Fan, B.; Song, M.; Jin, C.; Ma, J.; Li, R. Catal. Commun. 2006, 7, 969.

9. Venkatachalam, G.; Ramesh, R.; Inorg. Chem. Commun. 2005, 8, 1009.

10. He, Y.; Cai, C. Cat. Comm. 2011, 12, 678.

11. Tan, R.; Li, C.; Peng, Z.; Yin, D. Catal. Commun. 2011, 12, 1488.

12. Nair, M. S.; Arish, D.; Joseyphus, R. S. J. Saudi. Chem. Soc. 2012, 16, 83.

13. Holla, B. S.; Veerendra, B.; Shivananda, M. K.; Poojary,
B. Eur. J. Med. Chem. 2003, 38, 759.

14. Silva, C. M.; Silva, D. L.; Modolo, L. V.; Alves, R. B.; Resende, M. A.; Martins, C. V. B.; Fatima, A. J. $a d v$. Res. 2011, $2,1$.

15. Sylvain, R.; Bernier, J. L.; Waring, M. J. J. Org. Chem. 1996, 61, 23.

16. Santanu, B.; Subbrangsu, S. M. J. Chem. Soc. Chem. Commun. 1995, 24, 2489.

17. Gravert, D. J.; Griffin, J. H. J. Org. Chem. 1993, 58, 820.

18. Moreno, D.; Daier, V.; Palopoli, C.; Tuchagues, J. P.; Signorella, S. Inorg. Biochem. 2010, 104, 496.

19. Shaker, A. M.; Awad, A. M.; Nassr, L. A. E. Synth. React. Inorg. Met. Org. Chem. 2003, 33, 103.

20. Sharma, P. K.; Dubey, S. N. Ind. J. Chem. 1994, 33A, 1113.

21. Abdel-Rahman, L. H.; El-Khatib, R. M.; Nassr, L. A. E.; Abu-Dief, Aorg. M. J. Mol. Struct. 2013, 1040, 9.

22. Kirker, G. W. Org. Prep. Proced. Int. 1980, 12, 246.

23. Barry, A. L. The Antimicrobial Susceptibility Test, Principles and Practices; Illus Lea, Febiger, Eds.; Philadeliphia, PA, USA. 1976, p 180.

24. Baver, A.; Kirby, W. M. M.; Sherris, J. E.; Turck, M. Am. J. Clin. Pathol. 1986, 45, 493.

25. Biradar, N. S.; Karajagi, G. V.; Aminabhavi, T. M. Inorg. Chim. Acta 1984, 82, 211.

26. Biradar, N. S.; Kulkarni, V. H. J. Inorg. Nucl. Chem. 1971, 33, 2451.

27. Chen, D.; Martell, A. E.; Sun, Y. Inorg. Chem. 1989, 28, 2647.

28. Boghaei, D. M.; Gharag, M. Spectrochim. Acta 2006, 63A, 139.

29. Abd El-wahed, M. G.; Hassan, A. M.; Hammad, H. A.; El-Desouky, M. M. Bull. Korean Chem. Soc. 1992, 13, 113.

30. Zaki, Z. M. Spectrochem. Acta 2000, 56A, 1917.

31. Canpolat, E.; Kaya, M. J. Coord. Chem. 2000, 55, 961.

32. El-Tabl, A. S.; EL-Saied, F. A.; Al-Hakimi, A. N. J. Coord. Chem. 2008, 61(15), 2380.

33. Abu-Gharib, E. A. J. Ind. Chem. Soc. 1994, 71, 537. 